\title{
Impact of Chlorine Doping on the Performance of Perovskite Solar Cells
}

\section{Fatih Mehmet COSKUN $^{1^{*}} \quad$ Sakir AYDOGAN $^{2}$}

\begin{abstract}
In this paper the effect of $\mathrm{Cl}$ doping on optical, photovoltaic and morphological properties of mixed halide perovskite $\left(\mathrm{CH}_{3} \mathrm{NH}_{3} \mathrm{PbI}_{3-\mathrm{x}} \mathrm{Cl}_{\mathrm{x}}\right)$ structure in a solar cell has been reported. The perovskite layer was spin-coated by employing sequential deposition method over a PEDOT-PSS hole transport layer. Lastly, the device was finished by coating Al via thermal evaporation. The addition of $10 \%$ methylammonium chloride $(\mathrm{MACl})$ by weight into the methylammonium iodide (MAI) solution as additive was improved the photovoltaic performance of the solar cell, since the $\mathrm{Cl}$ doping has positive effect on the growth of perovskite crystals in the final film. Furthermore, addition of MACl enables the formation of smoother films and thus reduces photocurrent leakage due to pinholes or incomplete surface coverage. The $\mathrm{Cl}$ doping also increases reproducibility of planar devices for consistent device results.
\end{abstract}

Keywords: Halide Perovskite Solar Cells, Cl Doping

\footnotetext{
${ }^{1}$ Fatih Mehmet COSKUN (Orcid ID: 0000-0001-8040-8054), Department of Engineering Physics, Istanbul Medeniyet University, Istanbul, Turkey

2 Sakir AYDOGAN (Orcid ID: 0000-0001-5190-8121), Department of Physics, Faculty of Science, Ataturk University, Erzurum, Turkey.

*Sorumlu Yazar / Corresponding Author: Fatih Mehmet COSKUN, e-mail: fatih.coskun@medeniyet.edu.tr This work is part of Fatih Mehmet COSKUN's phD thesis.
} 


\section{INTRODUCTION}

Mixed halide perovskite solar cells have been the most advantageous photovoltaic devices in recent years because of their cheap precursor materials and easy fabrication procedures (Gao et al., 2014). Being an inexpensive alternative to silicon based photovoltaic devices; perovskite photovoltaic technology has now exceeded $19 \%$ power conversion efficiency (PCE) (Zhou et al., 2014). $\mathrm{CH}_{3} \mathrm{NH}_{3} \mathrm{PbI}_{3}$ perovskite absorber is generally used in mesostructured cells using solution processing whereas $\mathrm{CH}_{3} \mathrm{NH}_{3} \mathrm{PbI}_{3-\mathrm{x}} \mathrm{Cl}_{\mathrm{x}}$ perovskite absorber has been mostly exploited in planar devices. The success of mixed halide perovskite absorbers in planar devices has attracted researchers' interest as to why such films outperform standard $\mathrm{CH}_{3} \mathrm{NH}_{3} \mathrm{PbI}_{3}$ perovskite films (Tidhar et al., 2014; Dharani et al., 2014; Yu et al., 2014; Zhao and Zhu, 2014) However, it is clear that more research is needed to understand the role of $\mathrm{Cl}$ in perovskite film formation mechanism. There is also a need for development of novel methods that could yield reproducible device performances as well.

In order to achieve high PCE figures in perovskite solar cells, smooth films with high surface coverage is needed to avoid pinholes and thus leakage of generated photocurrent. $\mathrm{CH}_{3} \mathrm{NH}_{3} \mathrm{PbI}_{3-\mathrm{x}} \mathrm{Cl}_{\mathrm{x}}$ perovskite absorber has been widely used in the literature in high efficiency devices (Noel et al., 2014). It has been found that $\mathrm{Cl}$ incorporation in annealed $\mathrm{CH}_{3} \mathrm{NH}_{3} \mathrm{PbI}_{3-\mathrm{x}} \mathrm{Cl}_{\mathrm{x}}$ films is minimal (3-4\%), but chloride ion doping dramatically improves charge transport (Colelle et al., 2013). Yu et al. (2014) also confirmed that negligible amount of $\mathrm{Cl}$ atoms are present in the perovskite film after annealing and the function of $\mathrm{Cl}^{-}$is to facilitate the release of excess $\mathrm{CH}_{3} \mathrm{NH}_{3}{ }^{+}$. Indeed, Dualeh et al. (2014) reported that the sublimation enthalpy of $\mathrm{CH}_{3} \mathrm{NH}_{3} \mathrm{Cl}(78 \pm 2 \mathrm{~kJ} / \mathrm{mol})$ is smaller than that of $\mathrm{CH}_{3} \mathrm{NH}_{3} \mathrm{I}(105 \pm 5 \mathrm{~kJ} / \mathrm{mol})$, explaining the low content of chlorine atoms in the final perovskite film after annealing. A recent study revealed that the complete removal of $\mathrm{CH}_{3} \mathrm{NH}_{3} \mathrm{Cl}$ (MACl) is vital on the photovoltaic performance of the perovskite films (Xie et al., 2015)

Chlorine atoms have been found to act as heterogeneous nucleation sites, enabling slow and smooth crystallization of perovskite film (Tidhar et al., 2014). The presence of $\mathrm{MACl}$ in spin casting solution greatly affects crystallization process, leading to enhanced absorption and better coverage of substrate surface (Zhao and Zhu, 2014). The $\mathrm{Cl}$ atoms can have a huge impact on the photovoltaic performance. Zuo and Ding (2014) used $\mathrm{CH}_{3} \mathrm{NH}_{3} \mathrm{Cl}$ and $\mathrm{NH}_{4} \mathrm{Cl}$ as additive in precursor $\mathrm{MAI}: \mathrm{PbI}_{2}$ solution. The devices performed rather poorly without additives, whereas a PCE of $9.75 \%$ could be obtained by using $\mathrm{NH}_{4} \mathrm{Cl}$ as additive and a record $80.11 \%$ fill factor (FF) could also be measured.

Planar perovskite solar cells have shown device performances similar to mesoporous perovskite solar cells, which incorporate $\mathrm{TiO}_{2}$ or $\mathrm{Al}_{2} \mathrm{O}_{3}$ skeleton in electron collection layer. Here, we adopt planar perovskite solar cell structure with an aim to understand the role of $\mathrm{Cl}$ doping on photovoltaic performance and film forming properties of perovskite layer. In the literature, in order to optimize the device fabrication, there are a lot of records that report the sequential deposition method of $\mathrm{PbI}_{2}$ and then introduction of MAI onto $\mathrm{PbI}_{2}$ film by either spin coating or evaporation (Chen et al., 2014; Burschka et al., 2013; Xiao et al., 2014). Yet to our knowledge, none of those studies exploit the use of methylammonium halide mixture in formation of perovskite film. Here, we have systematically varied $\mathrm{Cl}$ amount in the solutions prepared for spin casting. Our results reveal that the presence of $\mathrm{Cl}$ significantly affects the perovskite crystallization and can be used to achieve 
reproducible device performances for consistent results. This study is not intended to fabricate the highest efficiency solar cell, but to determine the effect of $\mathrm{Cl}$ doping on film forming properties and PCEs of $\mathrm{CH}_{3} \mathrm{NH}_{3} \mathrm{PbI}_{3-\mathrm{x}} \mathrm{Cl}_{\mathrm{x}}$ mixed halide perovskite solar cells.

\section{MATERIALS AND METHODS}

In the scope of this study perovskite solar cells were fabricated on patterned indium tin oxide (ITO) glasses with a sheet resistance of $10 \Omega \mathrm{sq}^{-1}$. The cleansing procedure of ITO glasses is sequential ultrasonic treatment in deionized water, acetone and isopropanol (IPA) bath, and finally a bench-top plasma cleaning procedure (PE-50 bench top cleaner, The Plasma Etch, Inc., USA) for $2 \mathrm{~min}$. Poly(3,4-ethylene dioxythiophene):poly(styrene sulfonate (PEDOT:PSS) solution ${ }^{1} \quad$ (Heraeus Clevious pH 500) was spin coated - by filtering via a $0.45 \mu \mathrm{m}$ filter - at $4000 \mathrm{rpm}$ for $60 \mathrm{~s}$ on the ITO coated glass substrate. Then, the PEDOT: PSS layer was baked at $140{ }^{\circ} \mathrm{C}$ for $10 \mathrm{~min}$ in the air. The PEDOT: PSS coated substrates were then transferred to a $\mathrm{N}_{2}$ filled glovebox.

$\mathrm{CH}_{3} \mathrm{NH}_{3} \mathrm{I}$ (MAI) and $\mathrm{MACl}$ were synthesized according to cited literature (Zhao and Zhu, 2014). $\mathrm{PbI}_{2}$ and MAI:MACl blends were dissolved in N,Ndimethylformamide (DMF) and IPA with a concentration of $250 \mathrm{mg} / \mathrm{mL}$ for $\mathrm{PbI}_{2}$, and 10 $\mathrm{mg} / \mathrm{mL}$ for blends, respectively. By using the $\mathrm{MACl}$ and MAI stock solutions in appropriate amounts, six different MAI:MACl blend solutions were

\footnotetext{
${ }^{1}$ PEDOT:PSS is an intrinsically conductive polyelectroliyte polymer (Elschner et al, 2011), which is purchased commercially. The polymerization of ethylene dioxythiophene (EDOT) catalyzed by Fe(III) in the presence of excess peroxydisulfate. PEDOT:PSS is soluable in water and almost transparent after spin-coated on a glass. PEDOT:PSS thin films shows conducting property (Tait et al, 2013) and is commonly used as a hole transport layer (HTL) in conventional polymer solar cells (Zhao et al, 2015).
}

prepared in which weight percentages of $\mathrm{MACl}$ varies as $0 \%, 1 \%, 5 \%, 10 \%, 20 \%$, and $40 \%$ in comparison to total solid content (MAI + MACl). All of the solutions were heated on a hot plate to ensure MAI, $\mathrm{MACl}$ and $\mathrm{PbI}_{2}$ are fully dissolved for subsequent use. The $\mathrm{PbI}_{2}$ solution was spun on PEDOT: PSS coated substrate at 3,000 rpm for $20 \mathrm{~s}$ and then the resultant film was dried on a hot plate at $70{ }^{\circ} \mathrm{C}$ for $5 \mathrm{~min}$. The MAI:MACl blend solution was dropped onto the $\mathrm{PbI}_{2}$ coated substrate and waited for $20 \mathrm{~s}$. Then, the substrate was spun at 2 $000 \mathrm{rpm}$ and then $5000 \mathrm{rpm}$ for $20 \mathrm{~s}$ each. During the second spin coating step, the substrate was treated with 4-5 drops of toluene (Jeon et al., 2014). The films were annealed at $110{ }^{\circ} \mathrm{C}$ for 1 hour. Then, the phenyl-C61-butyric acid methyl ester (PCBM) solution (dissolved in ortho-dichlorobenzene with a concentration of $20 \mathrm{mg} / \mathrm{mL}$ ) was spin coated on top of the perovskite layer at $1500 \mathrm{rpm}$ for $35 \mathrm{~s}$. The substrate was annealed at $100{ }^{\circ} \mathrm{C}$ for $10 \mathrm{~min}$. The device was finished by evaporating $\mathrm{C}_{60}(20 \mathrm{~nm})$, bathocuproine $^{2}(\mathrm{BCP})(8 \mathrm{~nm})$, and $\mathrm{Al}(60 \mathrm{~nm})$ in a base pressure of $2 \times 10^{-6}$ mbar. The device area was defined through a shadow mask from the overlap of the ITO and aluminum electrodes $\left(10.9 \mathrm{~mm}^{2}\right)$.

The current density-voltage $(\mathrm{J}-\mathrm{V})$ measurement of the devices was conducted on a computer controlled Keithley 2600 source meter under the light of an AM1.5 - Global Reference Spectrum - solar simulator with Class-A. Absorption spectra of the films were performed by a Shimadzu UV-2600 UV-Vis spectrophotometer.

2 BCP is a polymer which is a derivative of 1,10phenanthroline with two methyl groups. This material is commonly used as a thin layer for the improvement of the electron transport in organic semiconductors (Liu and $\mathrm{Wu}$, 2012). BCP has a high ionization energy of $6.5 \mathrm{eV}$ (Hill and Khan, 1999), thus it facilitates the electron transport mechanism from the absorber layer to the cathode (Peumans et al, ). 
Atomic force microscopy (AFM) images of the samples were taken through a ParkSystems XE100E microscope. The grain sizes were calculated by ParkSystems Corp. XEI software using watershed method. X-ray diffraction (XRD) measurements were performed with a Bruker D8 Discover X-ray diffractometer with copper $\mathrm{K}-\alpha$ target X-ray tube. Film thickness measurements were determined with Ambios XP-200 step profiler.

\section{RESULTS AND DISCUSSION}

The device architecture used in this study is given in the inset of Figure 1a.
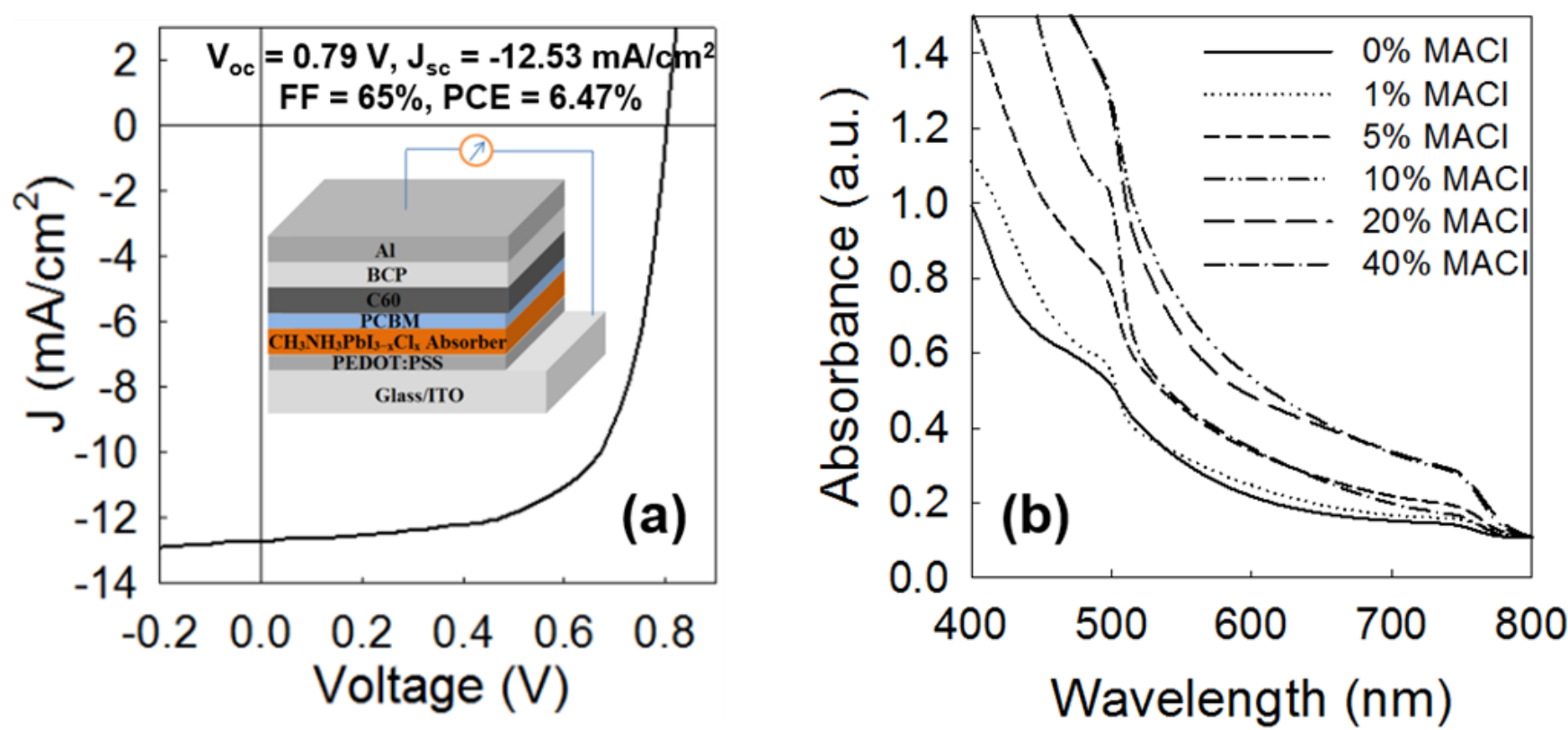

Figure 1. (a) $\mathrm{J}-\mathrm{V}$ characteristics of the best device with $10 \% \mathrm{MACl}$ doping is given along with the device architecture used in this work. (b) The variation of optical absorbance of perovskite films with MACl doping. Note that the data are normalized at $800 \mathrm{~nm}$ for better visualization of perovskite onset absorption among various films.

Table 1 demonstrates the photovoltaic parameters of the solar cells fabricated at various $\mathrm{MACl}$ doping levels. The devices without $\mathrm{Cl}$ doping almost showed negligible photovoltaic activity. The highest photovoltaic activity has been observed for the devices doped with $10 \% \mathrm{MACl}$. The best device gave a PCE of $6.47 \%$ with an open circuit voltage $\left(\mathrm{V}_{\mathrm{oc}}\right)$ of $0.79 \mathrm{~V}$, a short-circuit density of $\left(\mathrm{J}_{\mathrm{sc}}\right)$ of $-12.73 \mathrm{~mA} \mathrm{~cm}^{-2}$, and FF of $65 \%$
(Figure 1a). In general, the FFs of the cells with other doping concentrations were low and this had high impact on the efficiencies of the cells measured. The parasitic resistive losses and high carrier recombination of carriers are the main causes of low FF values in photodiodes. Indeed, the measured series resistance $\left(R_{s}\right)$ of the cells was lowest for $10 \% \mathrm{MACl}$ doped solar cell while others possessed quite high $\mathrm{R}_{\mathrm{s}}$ values (see Table 1). 
Table 1. Average photovoltaic performance parameters of five devices at various MACl doping levels under simulated AM1.5G illumination at $100 \mathrm{~mW} \mathrm{~cm}^{-2}$.

\begin{tabular}{lcccccc}
\hline Device & \multicolumn{7}{c}{ MACl Doping Percentage } \\
\cline { 2 - 7 } Parameter & $0 \%$ & $1 \%$ & $5 \%$ & $10 \%$ & $20 \%$ & $40 \%$ \\
\hline $\mathrm{R}_{\mathrm{s}}\left(\Omega \mathrm{cm}^{-2}\right)$ & 71600 & 10870 & 206 & 164 & 4639 & 137731 \\
$\mathrm{~V}_{\mathrm{oc}}(\mathrm{V})$ & $0.70 \pm 0.01$ & $0.48 \pm 0.05$ & $0.57 \pm 0.23$ & $0.76 \pm 0.07$ & $0.45 \pm 0.09$ & $0.75 \pm 0.07$ \\
$\mathrm{~J}_{\mathrm{sc}}\left(\mathrm{mA} \mathrm{cm}{ }^{-2}\right)$ & $-0.38 \pm 0.35$ & $-1.03 \pm 0.43$ & $-10.08 \pm 2.85$ & $-11.57 \pm 1.01$ & $-7.22 \pm 2.25$ & $-0.46 \pm 0.34$ \\
$\mathrm{FF}(\%)$ & $10.3 \pm 2.0$ & $20.0 \pm 7.9$ & $33.7 \pm 9.1$ & $54.1 \pm 8.0$ & $29.7 \pm 16.1$ & $21.0 \pm 2.2$ \\
$\mathrm{PCE}(\%)$ & $0.02 \pm 0.01$ & $0.12 \pm 0.08$ & $2.26 \pm 1.59$ & $4.75 \pm 0.89$ & $1.16 \pm 0.92$ & $0.09 \pm 0.07$ \\
\hline
\end{tabular}

The relatively $\mathrm{R}_{\mathrm{s}}$ values for solar cells other than $10 \% \mathrm{MACl}$ doped solar cell could be due to incomplete perovskite formation and hence poor charge extraction from the active layer. It is important to note that device reproducibility is significantly enhanced by using $\mathrm{MACl}$ as additive.
Dharani et al. (2014) used sequential deposition method by spin coating $\mathrm{PbCl}_{2}+\mathrm{PbI}_{2}$ on a mesoporous $\mathrm{TiO}_{2}$ film. They found that best device performances could be obtained by $\sim 6 \%$ (w/w) $\mathrm{PbCl}_{2}$ doping, similar to our findings but with completely different device fabrication method.
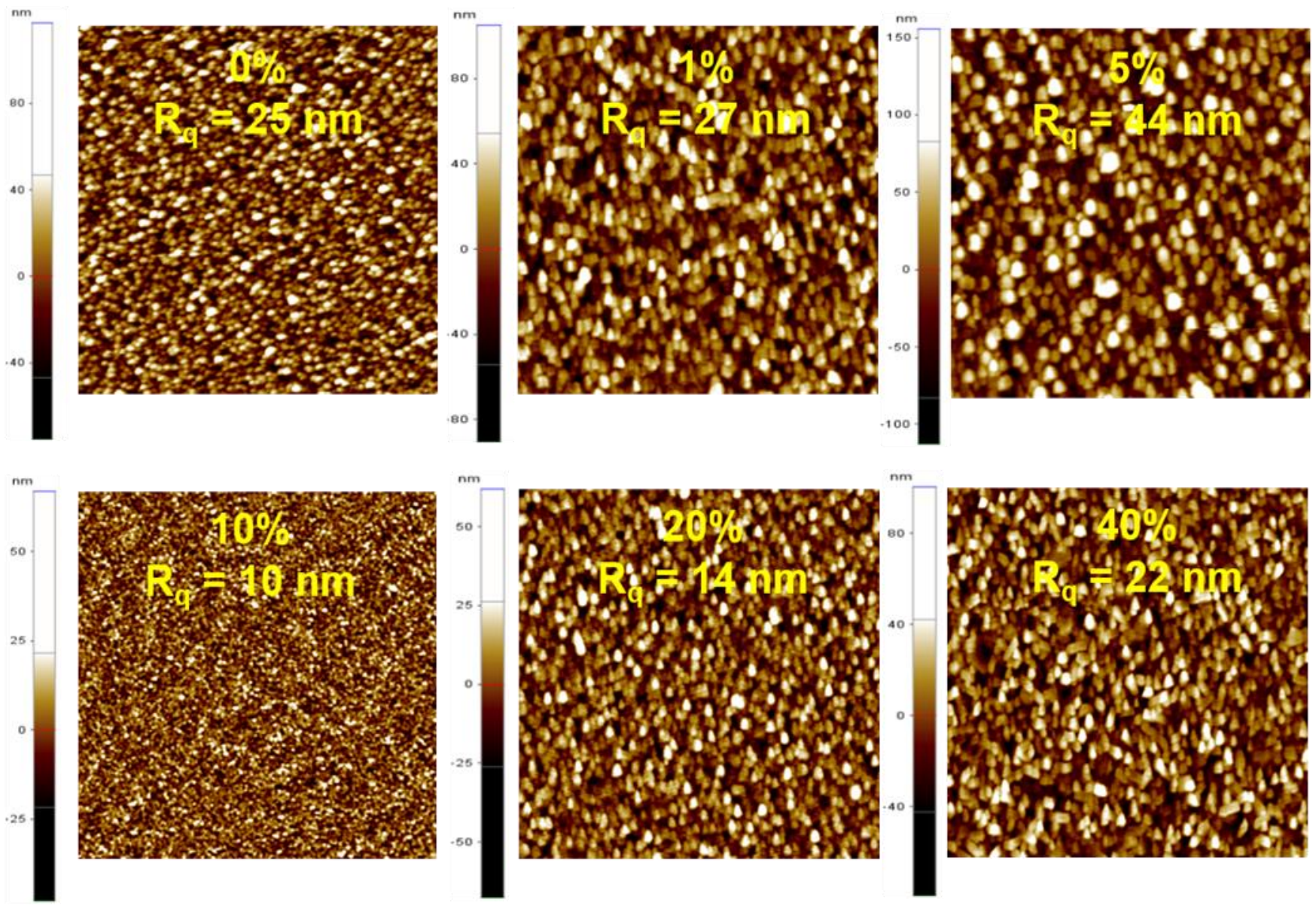

Figure 2. AFM topography images of perovskite films at various MACl doping concentrations. Each image has an area of 5x5 $\mu \mathrm{m}^{2} . \mathrm{R}_{\mathrm{q}}$ represents the surface roughness measured for each image. 
Optical absorbance of the films with and without $\mathrm{MACl}$ additive is given in Figure $1 \mathrm{~b}$. The extrapolated onset absorption of perovskite films gives a band gap of $1.57 \mathrm{eV}$, in agreement with the literature reports (Xiao et al., 2014). UV spectra have been referenced at $800 \mathrm{~nm}$ for better visualization of spectral differences among various films. There is little difference in the absorption profiles between $0 \%$ and $1 \%$ doped $\mathrm{MACl}$ films. The relatively low intensity of low energy peak at ca. $750 \mathrm{~nm}$ and a local maximum at ca. $500 \mathrm{~nm}$ indicates poor formation of perovskite crystals in both films. Upon further increase of $\mathrm{MACl}$ doping, both $500 \mathrm{~nm}$ and $750 \mathrm{~nm}$ peak absorptions increase in intensity. The highest absorption and most welldefined peaks are obtained for $10 \% \mathrm{MACl}$ doped film. At $20 \% \mathrm{MACl}$ doping, the perovskite film still display good light absorbing properties. Nonetheless, further enhancement in doping level (for example $40 \% \mathrm{MACl}$ film) shows less well defined $750 \mathrm{~nm}$ peak absorbance. That is, the extent of doping is critical to ensure that the highest absorption cross section is achieved in $\mathrm{CH}_{3} \mathrm{NH}_{3} \mathrm{PbI}_{3-\mathrm{x}} \mathrm{Cl}_{\mathrm{x}}$ thin films. The fact that the highest extinction coefficient is achieved with $10 \%$ $\mathrm{MACl}$ doped film correlates well with the device performance parameters given in Table 1. The typical thickness of perovskite films has been measured as $290 \mathrm{~nm}$, slightly smaller than the optimum thickness of $300 \mathrm{~nm}$ (Momblona et al., 2014).

AFM studies were performed to evaluate the quality of the films with doping level (see Figure 2 ). The surface roughness $\left(R_{q}\right)$ of the films changes considerably with $\mathrm{MACl}$ additive. $\mathrm{R}_{\mathrm{q}}$ values of $0 \%$ $\mathrm{MACl}$ and $1 \% \mathrm{MACl}$ film are essentially the same. The lowest $\mathrm{R}_{\mathrm{q}}$ value is obtained with $10 \% \mathrm{MACl}$ doped film. Further addition of additives makes the films non uniform.
All these results correlate very well with the device results given above. It is also interesting to note that grain size also changes with doping level. The median grain sizes are 369, 373, 400, 264, 285, and $351 \mathrm{~nm}$ for $0 \%, 1 \%, 5 \%, 10 \%, 20 \%$, and $40 \%$ $\mathrm{MACl}$ doped films, respectively. That is, the lowest grain size is achieved with $10 \% \mathrm{MACl}$ additive, in part explaining the low $\mathrm{R}_{\mathrm{q}}$ value measured for this film.

We further investigated the effect of $\mathrm{MACl}$ doping on crystallization with XRD technique. The major diffraction peak of $\mathrm{PbI}_{2}$ film was found at $12.8^{\circ}$, whereas low intensity diffraction peaks at $25.6^{\circ}, 38.8^{\circ}$, and $52.5^{\circ}$ can also be discerned (See Figure 3).

$\mathrm{MACl}$ doped films possess peaks that can be attributed to either $\mathrm{CH}_{3} \mathrm{NH}_{3} \mathrm{PbI}_{3}$ (Burschka et al., 2013) or $\mathrm{PbI}_{2}$ crystals. The diffraction peaks of $\mathrm{CH}_{3} \mathrm{NH}_{3} \mathrm{PbI}_{3}$ crystal at $14.3^{\circ}, 28.6^{\circ}$, and $43.3^{\circ}$ can be assigned to (110), (220), and (330) planes, respectively. The comparison of (110) plane peak of $\mathrm{CH}_{3} \mathrm{NH}_{3} \mathrm{PbI}_{3}$ crystal with respect to strong diffraction plane peak of $\mathrm{PbI}_{2}$ crystal can be used to evaluate the extent of perovskite film formation at various doping levels with chlorine atoms. In this regard, it can be said that the highest conversion of $\mathrm{PbI}_{2}$ crystals to perovskite crystal occur at $10 \%$ $\mathrm{MACl}$ doping level. The presence of $\mathrm{PbI}_{2}$ crystal diffraction peaks indicate the perovskite formation is not complete and may explain the relatively poorer device performances obtained from these films compared to state of art. The diffraction peaks for $0 \% \mathrm{MACl}$ film is quite weak compared to those of other films. Without additive, perovskite crystallization occurs slowly even though all of the films were annealed at $110^{\circ}$ for at least one hour. 


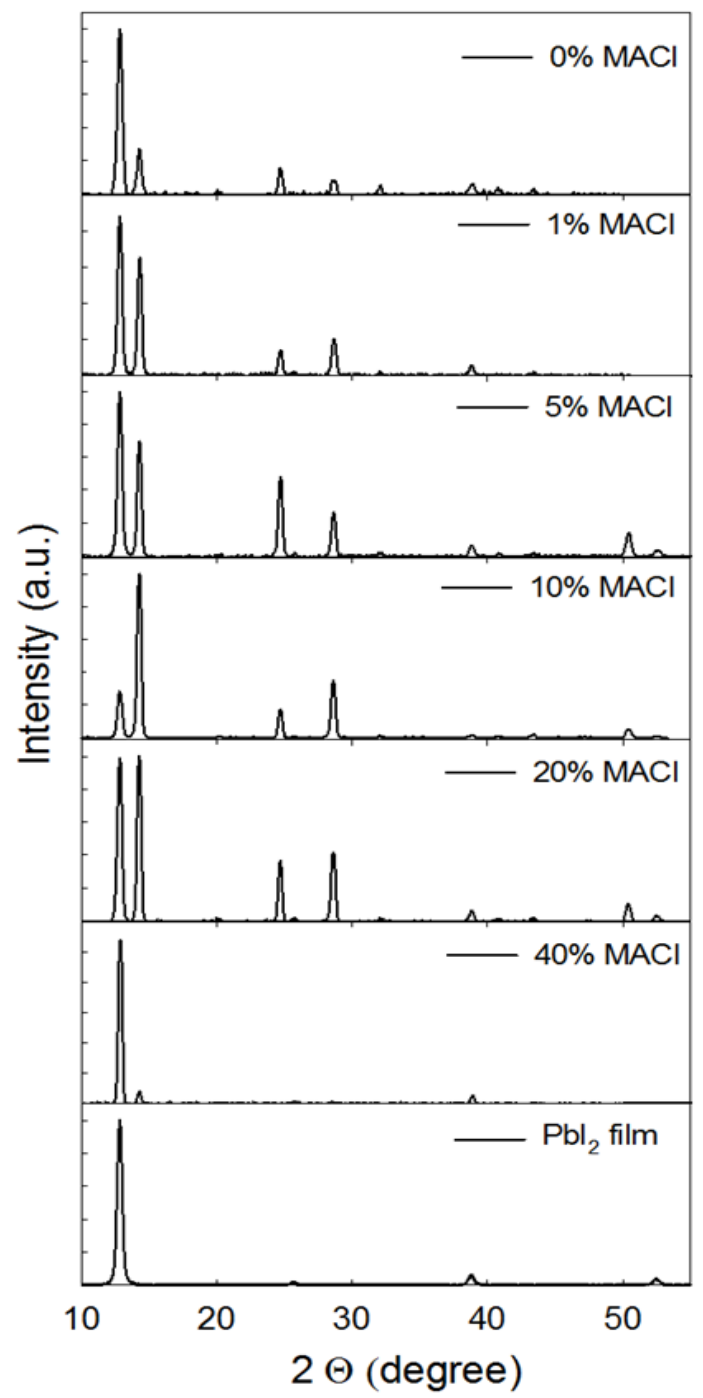

Figure 1. XRD spectra of $\mathrm{MACl}$ doped perovskite films and $\mathrm{PbI}_{2}$ film on glass substrates

\section{CONCLUSIONS}

In summary, we have used $\mathrm{MACl}$ additive for the first time in sequential deposition of perovskite films. In this new approach, $\mathrm{MACl}$ is added to MAI solution in order to adjust the crystallization of $\mathrm{CH}_{3} \mathrm{NH}_{3} \mathrm{PbI}_{3-\mathrm{x}} \mathrm{Cl}_{\mathrm{x}}$ film. The optimum $\mathrm{MACl}$ concentration has been found to be $10 \%$ by weight in MAI + MACl mixture dissolved in IPA. MACl as additive enhances optical absorption, induces faster crystallization of perovskite absorber, and also significantly improves surface morphology with decreased surface roughness on planar substrate. Compared to other methods used in fabrication of solar cells, the use of $\mathrm{MACl}$ as additive in sequential deposition method also improves reproducibility of photovoltaic performance. Such significant performance improvement is primarily attributed to the improved morphology and the better crystallization of perovskite absorber.

\section{ACKNOWLEDGMENTS}

FMC acknowledges the support by TUBITAK BIDEB 2211-C program for funding of this work. 


\section{REFERENCES}

Burschka J, Pellet N, Moon SJ, Humphry-Baker R, Gao P, Nazeeruddin MK, Gratzel M, 2013. Sequential deposition as a route to highperformance perovskite-sensitized solar cells. Nature, 499: 316-319.

Chen Q, Zhou HP, Hong ZR, Luo S, Duan HS, Wang HH, Liu YS, Li G, Yang Y, 2014. Planar Heterojunction Perovskite Solar Cells via Vapor-Assisted Solution Process. Journal of American Chemical Society, 136: 622625

Colella S, Mosconi E, Fedeli P, Listorti A, Gazza F, Orlandi F, Ferro P, Besagni T, Rizzo A, Calestani G, Gigli G, De Angelis F, Mosca R, 2013. $\mathrm{MAPbl}_{(3-\mathrm{x})} \mathrm{Cl}_{-\mathrm{x}}$ Mixed Halide Perovskite for Hybrid Solar Cells: The Role of Chloride as Dopant on the Transport and Structural Properties. Chemistry of Materials, 25: 4613-4618.

Dharani S, Dewi HA, Prabhakar RR, Baikie T, Shi C, Du Y, Mathews N, Boix PP, Mhaisalkar $\mathrm{SG}$, 2014. Incorporation of $\mathrm{Cl}$ into sequentially deposited lead halide perovskite films for highly efficient mesoporous solar cells. Nanoscale, 6: 13854-13860.

Dualeh A, Gao P, Seok SI, Nazeeruddin MK, Graetzel M, 2014. Thermal Behavior of Methylammonium Lead-Trihalide Perovskite Photovoltaic Light Harvesters. Chemistry of Materials, 26: 6160-6164.

Elschner A, Kirchmeyer S, Lovenich W, Merker U, Reuter K, 2011. PEDOT: Principles and Applications of an Intrinsically Conductive Polymer. CRC, pp. 50-99, New York-USA.

Gao P, Graetzel M, Nazeeruddin MK, 2014. Organohalide Lead Perovskites for Photovoltaic Applications. Energy \& Enviromental Science, 7: 2448-2463.

Hill IG and Kahn A, 1999. Organic Semiconductor Heterointerfaces Containing Bathocuproine. Journal of Applied Physics, 86:4515-4519.

Jeon NJ, Noh JH, Kim YC, Yang WS, Ryu S, Seol SIl, 2014. Solvent engineering for highperformance inorganic-organic hybrid perovskite solar cells. Nature Materilas, 13: 897-903.

Liu G and $\mathrm{Wu}$ Y, 2012. Bathocuproine. Encyclopedia of Reagents for Organic Synthesis, John Wiley\&Sons Publication.

Momblona C, Malinkiewicz O, Roldan-Carmona C, Soriano A, Gil-Escrig L, Bandiello E, Scheepers M, Edri E, Bolink HJ, 2014. Efficient methylammonium lead iodide perovskite solar cells with active layers from 300 to $900 \mathrm{~nm}$. APL Materials, 2: 081504.

Noel NK, Abate A, Stranks SD, Parrott ES, Burlakov VM, Goriely A, Snaith HJ, 2014. Enhanced Photoluminescence and Solar Cell Performance via Lewis Base Passivation of Organic Inorganic Lead Halide Perovskites. ACS Nano, 8: 9815-9821.

Peumans P, Bulovic V, Forrest SR, 2000. Efficient Photon Harvesting at High Optical Intensities in Ultrathin Organic Double-Heterostructure Photovoltaic Diodes. Applied Physics Letters, 76: 2650-2652.

Tait JG, Worfolk BJ, Maloney SA, Hauger TC, Elias AL, Buriak JM, Harris KD, 2013. Spray coated high-conductivity PEDOT:PSS transparent electrodes forstretchable and mechanically-robust organic solar cells. Solar Energy Materials \& Solar Cells, 110: 98-106. Tidhar Y, Edri E, Weissman, Zohar D, Hodes G, Cahen D, Rybtchinski B, Kirmayer S, 2014. Crystallization of Methyl Ammonium Lead Halide Perovskites: Implications for Photovoltaic Applications. Journal of American Chemical Society, 136: 1324913256. 
Xiao Z, Bi C, Shao Y, Dong Q, Wang Q, Yuan Y, Wang C, Gao Y, Huang J, 2014. Efficient, high yield perovskite photovoltaic devices grown by interdiffusion of solutionprocessed precursor stacking layers. Energy \& Enviromental Science, 7: 2619-2623.

Xie FX, Zhang D, Su H, Ren X, Wong KS, Gratzel M, Choy WCH, 2015. Vacuum-Assisted Thermal Annealing of $\mathrm{CH}_{3} \mathrm{NH}_{3} \mathrm{PbI}_{3}$ for Highly Stable and Efficient Perovskite Solar Cells. ACS Nano, 9: 639-646.

Yu H, Wang F, Xie F, Li W, Chen J, Zhao N, 2014. The Role of Chlorine in the Formation Process of " $\mathrm{CH}_{3} \mathrm{NH}_{3} \mathrm{PbI}_{3-\mathrm{x}} \mathrm{Cl}_{(\mathrm{x})}$ " Perovskite. Advanced Functional Materials, 24: 71027108.

Zhao $\mathrm{Y}$ and Zhu K, 2014. $\mathrm{CH}_{3} \mathrm{NH}_{3} \mathrm{Cl}$-Assisted One-Step Solution Growth of $\mathrm{CH}_{(3)} \mathrm{NH}_{(3)} \mathrm{Pbl}_{(3)}$ : Structure, Charge-Carrier Dynamics, and Photovoltaic Properties of Perovskite Solar Cells. Journal of Physical Chemistry C, 118: 9412-9418.
Zhao Z, Wu Q, Xia F, Chen X, Liu Y, Zhang W, Zhu J, Dai S, Yang S, 2015. Improving the Conductivity of PEDOT: PSS Hole Transport Layer in Polymer Solar Cells via Copper (II) Bromide Salt Doping. ACS Applied Materials and Interfaces, 7: 1439-1448.

Zhou H, Chen Q, Li G, Luo S, Song Tb, Duan HS, Hong Z, You J, Liu Y, Yang Y, 2014. Interface engineering of highly efficient perovskite solar cells. Science, 345: 542-546.

Zuo C, Ding L, 2014. An 80.11\% FF record achieved for perovskite solar cells by using the $\mathrm{NH}_{4} \mathrm{Cl}$ additive, Nanoscale, 6: 99359938. 